\title{
SISTEM BIKAMERAL DI INDONESIA SEBAGAI FUNGSI LEGISLASI DEWAN PERWAKILAN DAERAH DITINJAU DARI PERSPEKTIF MASLAHAH
}

\author{
Zainal Amaluddin \\ Institut Agama Islam Sultan Muhammad Syafiuddin Sambas \\ e-mail: zainalamaludin@gmail.com
}

\begin{abstract}
The Legislative Function of the Regional Representative Council The bicameral structure, especially in Indonesia, is viewed from a maslahah perspective. This study aims to analyze: (1) What is the legislative function of the Regional Representative Council in the bicameral system in Indonesia after the enactment of Law No.17 of 2014 concerning MD3, (2) What is the legislative function of the Regional Representative Council when viewed from the Maslahah perspective. This research is a type of normative legal research using two approaches, namely legislation and history. The statutory approach aims to examine in depth the various regulations governing the legislative duties and functions of the DPD, while the historical approach is used to understand the parliamentary system in Indonesia. After the data has been collected, the data is analyzed using descriptive analysis method which aims to describe the object under study in order to get a comprehensive picture. Furthermore, the data is analyzed based on maslahah theory using deductive methods because it analyzes through reasoning from a general form to achieve a special form. The results showed that: the legislative authority of the DPD which was originally expanded by the Constitutional Court in its decision No. 92 / PUU-X / 2012 apparently were not accommodated in the formulation of Law No.17 of 2014, this is evident in the MD3 Law that still contains several articles that again narrow down the constitutional authority of the DPD. If viewed from the maslahah perspective, the legislative functions of the DPD and Ahlul halli wal 'aqd in the Islamic constitutional system are very different. Although both have the same authority, namely in the field of legislation, the authority of Ahlul halliwal 'aqd is clearer and not as clear as the DPD legislation, besides that the DPD has not been placed equal to the DPR and the President in exercising its authority as a legislative institution especially after the enactment of Law No. .17 of 2014.
\end{abstract}

Keywords: Legislation Function, Regional Representative Council, Maslahah

\begin{abstract}
ABSTRAK
Penelitian ini bertujuan untuk menganalisa: (1) Bagaimana fungsi legislasi Dewan Perwakilan Daerah dalam sistem bikameral di Indonesia pasca berlakunya UU No.17 Tahun 2014 tentang MD3, (2) Bagaimana fungsi legislasi Dewan Perwakilan Daerah jika ditinjau dari prespektif Maslahah. Penelitian ini merupakan jenis penelitian hukum normatif dengan mengunakan dua pendekatan yakni perundang-undangan dan sejarah. Pendekatan perundang-undangan bertujuan untuk mengkaji secara mendalam berbagai peraturan yang mengatur terkait tugas dan fungsi
\end{abstract}


legislasi DPD, sedangkan pendekatan sejarah digunakan dalam rangka memahami sistem parlemen di Indonesia. Setelah data terkumpul, data dianalisis dengan menggunakan metode deskriptif analisis yang bertujuan untuk mendeskripsikan obyek yang diteliti sehingga mendapatkan gambaran secara menyeluruh. Selanjutnya data tersebut dilakukan analisis berdasarkan teori maslahah dengan menggunakan metode deduktif karena menganalisis melalui penalaran dari bentuk yang umum untuk mencapai suatu bentuk khusus. Hasil penelitian menunjukkan bahwa: kewenangan legislasi DPD yang semula di perluas oleh Mahkamah Konstitusi dalam putusanya No. 92/PUU-X/2012 ternyata tidak diakomodir dalam perumusan UU No.17 tahun 2014 hal ini terbukti dalam UU MD3 masih memuat beberapa pasal yang kembali mempersempit kewenangan konstitusional DPD. Jika ditinjau dari prespektif maslahah antara fungsi legislasi DPD dan Ahlul halli wal 'aqd dalam sistem ketatanegaraan Islam sangat berbeda. Meskipun keduanya mempunyai kewenagan yang sama yakni dalam bidang legislasi, tapi kewenangan Ahlul halliwal 'aqd lebih jelas dan tidak sumir seperti kewengan legislasi DPD, selain itu juga DPD belum ditempatkan setara dengan DPR dan Presiden dalam hal menjalankan kewenaganya sebagai lembaga legislatif terlebih pasca berlakunya UU No.17 Tahun 2014.

Kata Kunci: Fungsi Legislasi, Dewan Perwakilan Daerah, Maslahah

\section{PENDAHULUAN}

Indonesia memiliki lembaga negara salah satunya Dewan Perwakilan Rakyat, di mana tugas, wewenang, hak dan kewajiban serta fungsinya sudah diatur didalam undang-undang, yang mana di dalam aspek transisi di Indonesia merupakan puncak demokrasi perubahan di dalam sistem ketatanegaraan (Yusuf, 2013). Perubahan tersebut mengakibatkan didalam sturktural perlemen khususnya di Indonesia menjadi dua kamar atau disebut sebagai bikameral diantaranya lembaga Dewan Perwakilan Rakyat (DPR) dan Dewan Perwakilan Daerah (DPD). Kewenangan lembaga Dewan Perwakilan Daerah (DPD) didalam sistem tata negara kususnya di negara Indonesia mengalami berbagai persoalan, sehingga sangatlah sulit dan tidak teratur secara komprehensif sebagaimana yang tertuang didalam aturan Undang-undang tahun 1945 terkait pasal $22 \mathrm{C}$ serta pasal $22 \mathrm{D}$ dengan Undang-undang Nomor 27 Tahun 2009 diubah menjadi Undangundang Nomor 27 Tahun 2014 terkait dengan Majelis Permusyawaratan Rakyat (MPR) dan (DPR) Dewan Perwakilan Rakyat dan Dewan Perwakilan Daerah (DPD) serta Dewan Perwakilan Rakyat Daerah (DPRD) yang kemudian disebut dengan UU MD3 (Salmon, 2012)

Undang-undang tersebut menjelaskan bahwa DPD menjadi lembaga lagislatif didalam sistem perlementer kususnya di Indonesia, undangundang tersebut mengatakan bahwa kewenangan DPD tersebut masih termuat didalam pasal-pasal, bahwa mengeradikasi kekuasaan Konstitusional lembaga Dewan Perwakilan Daerah, sehingga mengakibatkan lembaga tersebut tidak efektif didalam menjalankan fungsinya sebagai lembaga legislatif. (Huda, 2014). Permasalahan yang menjadi titik tumpu antara kedudukan Dewan Perwakilan Rakyat dan 
Dewan Perwakilan Daerah terkait fungsi, tugas serta hubungan kelembagaan yang menjadi polemik, polemik tersebut menyangkut lembaga Dewan Perwakilan Daerah RI tidak lagi berfungsi, dipengaruhi oleh beberapa faktor yuridis yang menyebabkan lembaga DPD menjalankan fungsi kelembagaan didalam truktur ketatanegaraan repuklik Indonesia tidak efektif.

Terkait dengan masalah diatas bahwa kaitannya dengan al-maslahah berbica tentang manfaat atau kegunaan dalam berbagai aspek kehidupan dan dijauhi dari segi kejahatan dan kerusakan, maka dari itu pentingnya fungsi lembaga DPD dalam sistem bikameral dalam menyalurkan aspirasi masyarakat di dalam pembentukan Undang-undang, sekaligus menjalankan amanah yang telah diberikan oleh UU MD3 (Iqbal, 2014).

\section{METODE PENELITIAN}

Penelitian ini menggunakan metode Kualitatif dengan jenis penelitian hukum normatif (Ali, 2009) karena penelitian ini digunakan untuk meneliti bahan pustaka (Libarary Research) dengan menggunakan pendekatan Konseptual dan pendekatan perundang-undangan (Marzuki, 2010). Pendekatan perundang-undangan di gunakan untuk menganalisis secara detail terkait peraturan yang menyangkut tugas serta fungsi Dewan Perwakilan Daerah khususnya lembaga legislatif (Mamudji, 2006). Sedangkan pendekatan konseptual dipergunakan dalam rangka untuk memahami sistem parlemen yang di anut di Indonesia yakni pasca amandemen Undang-undang Dasar 1945 (Zainuddin, 2018).

\section{PEMBAHASAN}

A. Fungsi Legislasi Dewan Perwakilan Daerah Dalam Sistem Bikameral di Indonesia

Histori terstrukturnya DPD tidak terlepas dari unsur politik, budaya, ekonomi dan sosiologi yang merupakan rangka reformasi struktur perlemen di Indonesia sehingga menjadikan dua kamar yang disebut sistem bikameral. Kedua lembaga tersebut merupakan lembaga tinggi negara dengan dipilihnya melalui sistem demokrasi yakni pemilihan umum. (Cahyani, 2016), dengan adanya struktur bikameral tersebut dapat terselenggarakan berdasarkan sistem double-check yang mungkin representasinya untuk kemanfaatan seluruh manusia secara relatif dengan diarahkan dengan sistem sosial yang lebih meluas (Asshiddiqie, 2012).

Terkait dengan pasal 22D UUD 1945 dengan putusaan lembaga negara yaitu MK dengan Nomor 92/PUU-X/2012 mengatakan didalam perihal pemeriksaan terkait dengan RUU ataupun Revisi Undang-undang tentang hal kewenangan Dewan Perwakilan Daerah untuk ikut serta didalam proses pembahasan di awal sampai kepada tahap persetujuan atau pengesahan berdasarkan peraturan Nomor 17 tahun 2014 tentang MPR, DPR, DPD, dan DPRD atau Undang-undang MD3 terkait dengan rancangan Undang-undang yang akan di berlakukan. Manfaati DPD diperjelas dan dipertegas di dalam pasal 248 pada ayat (1) dengan bunyi sebagai berikut: (Undang-undang, 2014). 
Pertama, Pengajuan RUU kepada Dewan Perwakilan Rakyat yang berkenaanpada otonom, interaksi antara pusat dan daerah, penyusunan serta penyatuan kewilayahan dan mengatur SDM, ekonomi, dan lainnya.Kedua mengikut serta dalam pembahasan rancangan undangundang seperti yang dijelaskan dalam huruf aketiga, menata serta penyampaian daftar investasi masalah RUU yang berasal dari Dewan Perwakilan Daerah atau Presiden yang berkaitan dengan hal sebagaimana dimaksud huruf a keempat pemberian dalam pertimbangan kepada Dewan Perwakilan Daerah atas Rancangan Undang-Undangyang berkenaan dengan pajak, pendidikan, dan keagamaan. Kelima dapat melaksanakan pengamatan terhadap terapan UUberkenaan dengan otonompenyusunan terhadappeluasan, dan pebaruann daerah, desentralisasi dan dekonsentrasi sertamengatur SDM, SDA, implementasi Anggaran Pendapatan dan Belanja Negara, perpajakan, pendidikan, serta keagamaankeenam penyampaian penghasilan pengawasan terhadapimplementasiUU otonomi daerah terhadap penyususnan, peluasan, dan penyatuan daerah, pengelolaSDM, dan SDA, implementasi UU Anggaran Pendapatan dan Belanja Negara, perpajak, pendidikan, dan keagamaan kepada Dewan Perwakilan Rakyatyang menjadi evaluasikedepan supaya lebih baikketujuh menyusun program yang berkenaanterhadap otonomi daerah, pembaharuan, dan penyatuankedaerahan antara pusat dan daerah, pennyelenggaraanSDM, dan sumber daya ekonomi lainnya, serta yang berkaitan dengan pertimbangan keuangan pusat dan daerah.

Namun didalam pelaksanaannya DPD tidak ikut didalam proses pembentukannya (Undang-undang, 2014). Menurut para pakar ahli hukum tata negara yaitu Ni'matul Huda juga serupa, bahwa tidak diikutsertakan Dewan Perwakilan Daerah untuk pembahasan UU Nomor 17 Tahun 2014, untuk pembuatan UU tersebut cacat hukum baik dari segi formal, materil maupun mekanismenya (Huda, Hukum Tata Negara Indonesia, 2006).

Pasal 276 pada ayat (1) berbunyi Dewan Perwakilan Rakyat dapat mengajukan RUU berdasrkan Program Legislasi Nasional berdasarkan putusan Nomor 92/PUU-X/2012. Selain itu, Dewan Perwakilan Daerah mampumengusulkanRUU terhadaphimpunan komulatif berpraktikdidalam kondisi terbatas terhadap DPR, sedangkan Dewan Perwakilan Daerah dan Presiden ikut serta mengajukan RUU diluar dari Program Legislasi nasional. Dilihat dari sini bahwa ketentuan diatas memberikan ruang gerak kepada DPD sebagai tanggung jawab legislasi dipersempit, disebabkan tidak bisa menyampaikan RUU di luar Prolegnas.

Pasal 165 pada ayat (1) bertentangan dengan keputusan Mahkamah Konstitusi yang mana Dewan Perwakilan Daerah tidak diikutsertakan di dalam pengambilan keputusan atau persetujuan, bahwa permasalahan yang dibahas tentang daerah, selain itu juga terdapat pasal 71 pada hurus c yang mengatakan RUU di ajukan kepada Presiden atau Dewan Perwakilan Rakyat yang menyangkut daerah melibatkan DPD sebelum ada kesepakatan antara DPR dengan Presiden. Pasal 71 mengatakan kontradiktif dengan pasal 22 D Undang-undang Dasar 1945 yang mana memberi wewenang terhadap Dewan Perwakilan Daerah untuk menganalisis masalah tentang daerah. 
Terkait dengan Pasal 174 ayat (1), Dewan Perwakilan Rakyat menerima serta tindak lanjut terhadap pertimbangan tertulis terkait dengan RUU terhadapAPBN dan RUU yang berkenaan dengan perpajakan, pendidikan, keagamaan yang akan tersampaikan oleh lembaga DPD sebelum memasuki proses pembahasan antara DPR dengan Presiden Republik Indonesia. Ketentuan tersebut bertentangan dengan Pasal 22 D ayat (2) dikarenakan Dewan Perwakilan Daerah hanya diberikan kesempatan untuk menyampaikan pendapat sebelum pada tahap kesepakatan Rancangan Undang-Undang. Secara konstitusional harusnya Dewan Perwakilan Daerah untuk menentukan keputusan apakah menolak dan menyetujui Rancangan Undang-Undang yang telah dibahas dan selanjutnya akan menentukan sikap dari Dewan Perwakilan Daerahyang tentunya akan menjadi bahan pertimbangan Dewan Perwakilan Rakyat dengan Presiden.

Pasal 249 huruf b, Dewan Perwakilan Daerah terikut menganalisis RUU yang berkenaan terhadap daerah. Keputusan tersebut memudarkan sebelah selaku subjek analisis rancangan undang-undang. Ketidakjelasan tersebut dilaksanakan secara berencana dengan hilangnya keberlakuan yang secara jelas terhadap kewenangan pada Dewan Perwakilan Daerah untuk "ikut menganalisa" Rancangan undang-undang terkait Pasal 224 ayat (1) huruf b dan huruf c UU Nomor 27 tahun 2009.

Menyangkut Pasal 249, 224 pada ayat (1) huruf b dan c tersebut merupakan Pasal-Pasal yang mereduksi atas kewenangan lembaga Dewan Perwakilan Daerah selaku yurisprudence, maka perlembagaan tersebut seakan-akan menjadi subordinat dari Dewan Perwakilan Rakyat, padahal Dewan Perwakilan Daerah sebagai lembaga negara yang mempunyai legitimasi yang sama kuatnya dengan Dewan Perwakilan Rakyat yang dipilih serta mendapatkan mandatsari secara langsung dari rakyat, selayaknya Dewan Perwakilan Daerah diposisikan setara dengan Dewan Perwakilan Rakyat di dalam menjalankan tanggung jawab sebagai legislasi dimulai pada tahap pengajuan, pengkajian sampai pada tahap terakhir yakni penentuan ketetapan.

Penjelasan data di atas telah membuktikan betapah lemahnya peran dan fungsi Dewan Perwakilan Daerah ketimbang Dewan Perwakilan Rakyat, dengan lemahnya peran dan fungsi Dewan Perwakilan Daerah tersebut sebagai perwujudan perwakilan daerah ketidakjelasan terhadap kedaulatan rakyat serta check and balances di dalam kehidupan berkonstitusi dan ketatanegaraan di Indonesia. Dewan Perwakilan Daerah memang menjadikan lembaga yang tidak mempunyai akhir kewenangan, lembaga DPD tersebut bisa menyampaikan RUU, tetapi bergantung pada Dewan Perwakilan Rakyat (Harun, 2012).

Berdasarkan data terkait kegunaan legislasi DPD di dalam struktur bikameral di Indonesia adalah lemahnya kewenangan Dewan Perwakilan Daerah di dalam menjalankan tugas legislasi yang sesungguhnya telah menjadi permasalahan yang sangat lama pendapat dari pengembangan dari struktur chek and balances yang ada pada tubuh parlemen, hanya saja terjadi kemudian lemahnya lembaga Dewan Perwakilan Daerah menjadi utama dalam kamar di parlemen untuk melaraskan kamar lain, yaitu 
Dewan Perwakilan Rakyat. Dengan mengakibatkan relasi antara cabang kewenangan yang belum memperoleh keberhasilan, penghormatan, dan akuntabilitas terhadap kontruksi dan kewajiban di masing-masing lembaga negara (MD, 2011).

Kesimpulan dari dua kubu tersebut pada puncak melahirkan kesepakatan dasar yang menyebabkan amandemen tidak dapat terlaksana dengan leluasa untuk dapat diselaraskan dengan ilmu-ilmu tentang peraturan tertulis dan tidak tertulis. Kesepakatan dasar itulah memuat lima macam, di antaranya:

1. Pembukaan Undang-undang Dasar 1945 tidak diubah

2. Tetap menjaga Negara Kesatuan republik Indonesia

3. Mempejelas struktur presidensial

4. Penjelasan Undang-undang Dasar 1945 yang isinya tentang hal-hal yang berkaitan dengan normatif akan dimaksukkan di dalam pasal-pasal

5. Pegantian dilaksanakan dengan sistem adendum.

Dapat ditarik kesimpulan bahwa keputusan Mahkamah Konstitusi secara normatif harusnya keputusan yang termaktub di dalam UU Nomor 17 tahun 2014, mesti sesuai dan proses sesuai apa yang menjadi penetapan dari lembaga MK dalam putusanya Nomor 92/PUU-X/2012 terkait dengan fungsi legislasi DPD Jika tidak, hal ini tentunya akan memberikan kesulitan Dewan Perwakilan Daerah di dalam mempertahankan tanggung jawab selaku terpilihnya sebagai lembaga dari oleh rakyat dan memberikan dasar oleh rakyat sebagai perwakilan dari daerah, guna untuk ikut dalam mempertahankan hak konstitusional kususnya di daerah di dalam penerimaan keputusan maupun keputusan oleh pusat. Sisi lain pula memperjelas struktur bikameral yang telah diakui di Indonesia, karena selama ini ide bikameral di Indonesia dikatakan "rancu" dikarenakan tidak adanya pengaturan yang imbang antara Dewan Perwakilan Daerah dengan Dewan Perwakilan Rakyat khususnya di dalam segi legislasi, maka prosedur check and balances di antara lembaga legislatif menjadikan tidak jelas.

\section{B. Sistem Bikameral Di Indonesia Sebagai Fungsi Legislasi Dewan} Perwakilan Daerah Di Tinjau Dari Maslahah.

Sedangkan lembaga Dewan Perwakilan Daerah merupakan lembaga yang menyalurkan aspirasi dan kepentingan daerah yang berpusat kepada lembaga legislatif di mana di antara fungsinya adalah menciptakan UU dengan mempertimbangkan berbagai landasan yaitu landasan yuridis, sosiologis dan filosofis (Pirmansyah, 2014). Dalam pembahasan ini, kewenangan legislatif (al-sulthah al-tasri'iyah) yaitu kekuasaan atau kewenangan di dalam pemerintahan Islam untuk penetapan norma atau kaidah yang akan diberlakukan secara universal dan terapkan oleh manusia dengan berlandaskan syarat yang telah ditetapkan oleh Allah Swt dalam syariat Islam. Dalam literasi sejarah mengatakan, bahwa kekuasaan legislatif ini dilakukan oleh lembaga Ahlu ahalli wal Aqdi, yang kemudian di 
masa modern sekarang ini lembaga biasanya mengambil bentuk sebagai majelis syura atau disebut sebagai (parlemen).

Sedangkan Ahlu ahalli wal Aqdi secara bahasannya adalah "orangorang yang dapat melepas dan mengikat". Disebut sebagai "mengikat" karena keputusannya mengikat orang-orang yang mengangkat Ahlu al-halli, disebut "melepas" dikarena mereka yang duduk bisa melepaskan atau tidak memilih orang-orang tertentu yang tidak disetujui. Sedangkan menurut istilah para pakar ahli fiqih siyasah menterjemahkan pengertian Ahlu alhalli wal Aqdi sebagai orang-orang yang memiliki kewenangan untuk menetukan sesuatu atas nama umat, dengan kata lain Ahlu al-halli wal Aqdi adalah lembaga perwakilan yang menampung dan menyalurkan berbagai macam aspirasi suara masyarakat (Iqbal)

Al-Mawardi mengatakan bahwa Ahlu al-halli wal Aqdi dangan alikhtiyar ini lah yang berhak menentukan seorang pemimpin atau khalifah, dengan berbagai syarat yang harus dipenuhi (Mawardi) Sedangkan Ibnu Taimiyyah berkataAhlu al-halli wal Aqdi dengan ahl al-syawkah. An Nawawi dalam Al-Minhaj Ahlu al-halli wal Aqdi adalah para ulama', kepala, para pemuka masyarakat sebagai unsur-unsur masyarakat yang berusaha untuk mewujudkan kemaslahatan umat. (Umar, 1997). Beda halnya dengan Abu A'la al-Maududi, dia mengatakan bahwaAhlu al-halli wal Aqdi sebagai lembaga yang memberikan jalan tengan dan pemberi fatwa sekaligus sebagai menyebut sebagai lembaga legislatif. Sebagian lagi ada yang menyebut dengan ahl al-syura atau ahl al-ijma. Namun semuanya berpacu pada konsep 'sekelompok anggota masyarakat yang mewakili umat (rakyat) dalam menentukan arah dan kebijaksanaan pemerintahan demi terwujudnya kemaslahatan umat.

Pemaparan di atas menerangkan bahwa, Abdul Hamid al-Anshari berkata bahwa majelis syura yang menghimpun ahl al-syura merupakan sarana yang digunakan rakyat atau wakil rakyatnya untuk memperjuangkanpermasalahan kemasyarakatan. Dengan demikian, rakyatlah yang dapat menentukan nasibnya sesuai dengan kemaslahatan. Lembaga Ahlu al-halli wal Aqdi dalam sistem ketatanegraaan Islam menurut Abu a'la al-Maududi, memiliki beberapa tugas diantaranya :

1. Mempertahankan norma yang telah ditetapkandidalam aturan dan merumuskan suatu perundangan-undangan yang terikatpada seluruhterkait dengan hal-hal yang tidak diatur didalam Al- Qur'an dan Al-Sunnah;

2. Pedoman Al-Qur'an dan As-Sunnah memberikan interprestasi lebih dari satu, maka lembaga legislatif yang berkewajibanmenentukan penafsiran terkait mana yang layak untuk ditempatkan dalam kitab UU.

3. Masalah yang terdapat dalam Al-Qur'an dan As-Sunnah tidak memberikan pedoman yang sifatnya mendasar sekalipun, atau masalah ini juga tidak ada dalam konfensi Khulafa al-Rasiyydin, maka kita menterjemahkan bahwa Tuhan telah memberikan keleluasaan melakukan legislasi. Oleh karena itu, didalam masalahini, lembaga legislatif dapat melakukan perumusan hukum 
tanpa batasan, sepanjang tidak bertentangan dengan jiwa semangat syari'ah. (Sjadzali).

4. Pelaksanaan kewajibanmereka tidak hanya memusyawarahkandidalam perkara umum kenegaraan, melainkan mengeluarkan undang-undang yang menyangkuttentang kemaslahatan dan melaksanakan peran konstitusional didalam penentuan untuk di jadikan sebagai pemimpin tertinggi negara saja, tetapi mencakup peran pengawasan terhadap Goverment dan penguasa untuk tidak terjadi tindakan pelanggaran terhadap hak dari hak Allah Swt (Sjadzali).

Selain tugas tersebut Ahlu al-halli wal Aqdi juga memiliki beberapa kewenangan diantaranya :

1. Memberikan berbagai masukan dan saran kepada khalifah dalam aktifitas dan masalah praktis yang terjadi, semisal permasalah pemerintahan, pendidikan, kesehatan, ekonomi, perdagangan dan lainnya. Dalam hal ini opininya besifat mengikat.

2. Mengenai permasalah pemikiran yang membutuhkan penelitian dan analisa, serta masalah kedisiplinan, finansial, pasukan, politik luar negeri, khalifah berhak merujuk pada pandangan Majelis umat, namun dalam hal ini pandangan Majelis umat tidak mengikat.

3. Khalifah berhak menyodorkan undang-undang atau hukum yang hendak di adopsi kepada Majelis, Majelis berhak memberikan saran atau masukan serta menilai dan mengevaluasi meskipun tidak bersifat mengikat.

4. Majelis juga berhak membatasi kandidat calon khalifah sebagai wujud dari suksesi kekuasaan atau pemerintahan (Sjadzali).

Mencermati tugas serta fungsinya diatas, bahwa lembaga Ahlu al-halli wal Aqdi merupakan kewenanganyang meluas dalam pembentukanUU jika tidak adanya sebuah peraturannorma atau kaidah dalam Al-Qur'an maupun As-Sunnah. Lembaga Ahlu al-halli wal Aqdi diperbolehkan melakukan ijtihad hukum terhadap suatu permasalahan yang tidak ditemukan pengaturanya, sepanjang tidak bertentangan dengan jiwa dan semangat syari'ah.

Seharusnya kekuasaan tersebut dipunyai oleh lembaga DPD sebagai salah satu lembaga yang mempunyai kekuasaan legislasi di Indonesia meskipun tidak harus sama. Namun, paling tidakkewenangan tersebut dalam proses pengajuan dan membentuk undang-undang lebih dipertegas dan di perjelassama halnya dengan kewenangan Ahlu al-halli wal Aqdi dalam Islam.Kalau kita cermati selama ini pengaturan terkait fungsi legislasi DPD dalam sistem parlemen di Indonesia tidak diatur secara komperhensif seperti halnya kewenangan legislasi yang dimiliki Dewan Perwakilan Rakyat (DPR). Kewenangan lembaga Dewan Perwakilan Daerah dalam bidang legislasi hanya sebatas "dapat mengajukan" dan "ikut membahas" RUU yang berkenaan dengan daerah. Dari frase kata "dapat" dan "ikut" berarti Dewan Perwakilan Daerah tidak mempunyai keharusan dan hak inisiatif yang mandiri dalam pembentukan undang-undang meski 
terkait kewenangan yang telah diberikan. Selain itu pengaturanya dalam Undang-Undang No.17 tahun 2014 tentang MD3 dan Undang-Undang No.12 tahun 2011 tentang Pembentukan Peraturran Perundang-undangan atau disebut (UU P3) yang kembali mereduksi kewenangan konstitusional Dewan Perwakilan Daerah dengan tidak menempatkan Dewan Perwakilan Daerah setara dengan Dewan Perwakilan Rakyat dan, Presiden dalam setiap pengajuan, pembahasan Rancangan Undang-Undang yang menyebabkan sulitnya Dewan Perwakilan Daerah untuk menjalankan fungsinya sebagai lembaga yang memperjuangkan aspirasi kedaerahan dalam setiap pengambilan kebijakan dipusat.

Kewenangan Ahlu al-halli wal Aqdi dalam ketatanegaraan di dalam Islam, yang mana lembaga tersebut mempunyai kewenangan yang cukup luas serta segnifikan dalam menjalankan fungsinya sebagai lembaga legislatif. Hal tersebut bisa dilihat dalam sejarah ketatanegaraan di dalam Islam pasca wafatnya Rasullullah Saw, bahwa pada saat itu munculnya sebuah permasalahan yang sangat urgen dikalangan umat Islam yaitu masalah politik terutama masalah Imamah dan Kekhalifahan. Dalam masa tersebut, masyarakat Islam membutuhkan sosok seorang pemimpin baru, wilayah kekuasaan Islam yang membentang sampai wilayah sebagaian besar jazirah arab akan dengan mudahnya hancur atau terpecah belah kembali, di samping kekhawatiran adanya serangan dari bangsa-bagsa lain seperti dari bangsa Romawi dan persia sehingga stabilitas umat Islam saat itu teracam (Zahroh).

Oleh sebab itu, dalam sejarah Islam, dikenal berbagai mekanisme dan prosedur didalam penetapan kepala negara, dan tentu saja, dengan berbagai kriteria yang sesuai dengan sosioshistoris yang ada. Hal ini bisa dilihat pada masa al-khulafa' al-Rasyidin, empat khalifah pada masa itu dipilih dengan mekanisme yang berbeda-beda.

1. Pada saat pemilihan Abu Bakar AS menjadi khalifah yang dilakukan dengan "pemilihan suatu musyawarah" terbuka yang terjadi di Saqifah Bani Saidah.

2. Pemilihan Umar bin Khattab yang dilakukan berdasarkan "penunjukan kepala negara sebelumnya".

3. Pemilihan Ustman bin Affan di tetapkan berdasarkan "pemilihan dalam suatu dewan formatur" yang telah di bentuk oleh khalifah sebelumnya.

4. Pemilihan Ali bin Thalib ditetapkan berdasarkan pemilihan melalui musyawarah dalam pertemuan terbuka. (Djazuli) Al-Mawardi berpendapat bahwa pengangkatan Imamah dianggap sah jika dilakukan dengan dua cara. Pertama, pemilihan oleh Ahlu al-halli wal Aqdi, kedua, penunjukkan oleh imam (khalifah) sebelumnya.

Utsman berkata, ide yang banyak itu tidak terhitungsiapa yang menerima dan yang tidak, akan memunculkan masalah. Sedangkan AlWalid memberi masukan agar dibentuk dewan sebagaimana ia lihat di Syam, rajanya membentuk dewan. Umar bin Khattab akhirnya mengikuti saran Al-Walid. Lalu ia memerintahkan Aqil bin Abi Thalib, Makhramah bin Naufal dan Jabir bin Matham membuat dewan, yaitu daftar orang dalam 
laskar yang dikususkan menurut suku masing-masing, dan keputusan gaji yang harus mereka ambil dari hasil perpajakan dari daerah yang dikalahkan. (Al-Thabari)

Kejadian tersebut dapat diambil untukpemahaman bahwa Ahlu alhalli wal Aqdi memiliki peran yang sangat penting dalam penentuan arah dan keputusan yang akan di ambil oleh khalifah. Seorang khalifah dalam Islam tidak pernah mengambil sebuah kebijakan secara sepihak, tanpa terlebih dahulu bermusyawarah dengan Ahlu al-halli wal Aqdi, hal ini dilakukanya agar kebijakan yang akan diambil sesuai dengan kehendak dan keinginan masyarakat Islam pada saat itu. Hal ini jika direalisasikan dalam sistem ketatanegaraan Indonesia, berarti bahwa pemerintah dalam mengambil keputusan yang menyangkut kepentingan daerah seharusnya mulai dari tahap pengajuan, pembahasan sampai pada akhir pengambilan keputusan harus melibatkan Dewan Perwakilan Daerah selaku lembaga yang diberi mandat untuk mewakili rakyat di daerah. Hal ini bertujuan agar kebijakan yang diambil oleh pemerintah sesuai dengan kepentingan daerah.

Melihat saat ini, kepentingan daerah yang selama ini bertumpuh kepada Dewan Perwakilan Daerah tidak bisa di salurkan dengan baik, meskipun lembaga tersebut sudah berusaha memberikan pandangan atau usulan yang baik, yang diyakini sarat dengan kepentingan daerah, namun pada akhirnya akan mengalami kemandekan atas resistensi ketika muncul dalam pembahasan di Dewan Perwakilan Rakyat. Kondisi dilematis ini menjadikan lembaga Dewan Perwakilan Daerah tidak terlalu berdaya dalam memperjuangkan aspirasi konstitusinya (pemilihnya) dalam setiap eksekusi Rancangan Undang-Undang tertentu.

Sistem ketatanegaraan yang demokratis yang dilselengagarakan atas dasar kedaulatan rakyat, seharusnya dapat diartikan bahwa rakyatlah yang sesungguhnya pemilik negara dengan segala kewenangan untuk menjalankan semua fungsi kekuasaan negara dengan terpacu pada trias politica yakni di bidang legislatif, eksekutif maupun yudikatif, rakyatlah yang berwenang merencanakan, mengatur, melaksanakan, dan melakukan pengawasan serta memberikan penilaian terhadap pelaksanaan fungsi kekuasaan tersebut, dalam artinya rakyat mempunyai otoritas tertinggi untuk menetapkan berlaku dan tidaknya suatu ketentuan hukum dan mempunyai otoritas tertinggi untuk menjalankan dan mengawasi pelaksanaan hukum tersebut. Dari disini dapat ditarik benang merah bahwa keberadaan DPD dalam sistem ketatanegaraan di Indonesia dapat dikatakan rancu, karena lembaga tersebut dalam pembentukanya tidak dapat memperjuangkan aspirasi rakyak khususnya dalam bidang legislasi yang nantinya kan memberikan kepintingan maslahah.

Sedangkan Maslahah merupakan kata yang mempunyai arti dan makna tersendiri. Di lihat dari etimologi maslahah merupakan perbuatan yang memberikan kebaikan terhadap segala aspek baik materil maupun formil dengan mengedepankan kemaslahatan umat atas dasar syariat Islam.(Romli, 1999) Dalam bahasa arab Maslahah merupakan perbuatan yang mendorong kepada arah kebaikan manusia, sedangkan menurut Imam Malik suatu masalah ataupun perbuatan yang tujuan dan prinsip berpedoman kepada Al-quran, hadist, dalil-dalil syara' yang berfungsi dan 
sekaligus memberikan manfaat kepada diri sendiri maupun banyak orang.(al-syatibi, 1975). Berbagai pemaknaan terkait dengan maslahah maka penulis memberikan kesimpulan bahwa maslahah merupakan segala tindakan harus memberikan berbagai manfaat baik dari berbagai aspek yang pada akhinya untuk mewujudkan tujuan islam yang merupakan nilai dari kemaslahatan umat (Haq, 2007).

Berdasarkan analisis, penulis menyimpulkan bahwa antara Ahlu alhalli wal Aqdidan Dewan Perwakilan Daerah mempunyai korelasi yang sama yakni sebagai lembaga yang mempunyai fungsi membentuk undangundang. Namun demikian meskipun keduanya mempunyai fungsi yang sama tapi fungsi legislasi Ahlu al-halli wal Aqdilebih luas dari pada Dewan Perwakilan Daerah. Selain itu juga, disisi yang lain antara keduanya juga memiliki banyak perbedaan, diantaranya : Dari segi keanggotaanya. Di dalam sistem Ahlu al-halli wal Aqdianggotanya harus seorang muslim yang adil. Adapun dalam sistem parlemen, anggotanya tidak harus beragama Islam, orang komunis/ateis bisa menjadi anggota, bahkan menjadi ketua parlemen, selama rakyat mendukung. Di dalam sistem Ahlu al-halli wal Aqdianggotanya harus seorang laki-laki. Namun dalam sistem parlemen, perempuan di bolehkan menjadi anggota di dalamnya. Anggota Ahlu al-halli wal Aqdiharus seorang yang berpengetahuan luas terhadap ajaran Islam, sedangkan anggota parlemen boleh dari orang yang dangkal pengetahuanya dalam bidang agama.

Dari segi tugas dan peranannya Ahlu al-halli wal Aqdi harus sesuai dengan aturan syariah Islamiyah. Mereka tidak boleh mengubah aturan Allah dan Rasul-Nya yang sudah paten dan mapan, walau seluruh anggota dan rakyat menghendaki perubahan itu. Adapun dalam parlemen, mereka bebas dan leluasa menentukan hukum, undang-undang, dan bahkan mengubah aturan hukum Allah Swt selama hal itu disepkati oleh seluruh anggota atau atas kehendak rakyat.Ahlu al-halli wal Aqdi diwarnai dengan suasana ukhuwah, kekeluargaan, dan kerja sama di dalam kebaikan dan ketakwaan, sedangkan keanggotaan parlemen diwarnai rasa ta'ashub terhadap golongan, sektarian, dan penuh dengan persaingan yang tidak sehat. Dari perbandingan di atas dapat diketahui, bahwa dalam lembaga Dewan Perwakilan Daerah ternyata masih memiliki banyak perbedaan dengan Ahlu al-halli wal Aqdi.

Terkait tentang fungsi Dewan Perwakilan Rakyat dan Dewan Perwakilan Daerah sebagai lembaga bikameral perwakilan rakyat di indonesia secara maksimal, itu ada dua hal yang menjadi perhatian Pertama memberikan penjelasan terkait kewenangan yang dimiliki oleh lembaga Dewan Perwakilan Daerah sehingga memiliki kewenangan tersendiri, tidak hanya sekedar menjadi lembaga tetapi juga tersubordinasi oleh Dewan Perwakilan Rakyat melalui perubahan pasal didalam UU 17 tahun 2017 dan UUD 1945 yang mengatur tentang kewenangan DPR. Kedua menginisiasi adanya konvensi didalam menyelenggarakan pemerintahan diminta untuk memperhatikan pertimbangan yang di berikan oleh DPD yang bersifat mengikat kepada DPR.

Namun terlepas dari hal tersebut antara Ahlu al-halli wal Aqdi dan Dewan Perwakilan Daerah dan dewan perwakilan Rakyat merupakan 
sebuah lembaga yang mecerminkan representasi dari rakyat yang mempunyai fungsi membentuk undang-undang yang akan diberlakukan, keberlakuan tersebut tentunya universal tidak pandang status. Kedua lembaga tersebut antara DPR dan DPD yang mana didalam menjalankan fungsi serta tugas kewajiban hak dan kewenangan yag di berikan oleh UU tentunya sedikit banyaknya sudah di realisasikan meskipun banyak catatan yang belum terselesaikan, tetapi kedua lembaga tersebut di dalam proses awal sampai akhir di dalam pembuatan UU tentunya mengedepankan kepentingan umat bukan kepentingan diri sendiri maupun golongan dan pencapainya UU tersebut tentunyan demi kemaslahatan rakyat.

\section{KESIMPULAN}

Pasca berlakunya Undang-Undang No.17 tahun 2014 fungsi legislasi Dewan Perwakilan Daerah kembali reduksi. Hal terbukti bahwa dalam pembentukanya UU No.17 tahun 2014 tidak melibatkan DPD dalam pembahasanya, padahal kalau mengacu pada pada Pasal 22D UUD 1945 dan putusan Mahkamah Konstitusi No.92/PUU/X/2012 DPD mempunyai kewenangan ikut membahas sampai tahapan tingkat I terkait Rancangan undang-undang yang berkaitan dengan kewenangannya. Dalam sistem bikameral yang pure bicameralism antara majelis tinggi dan majelis rendah mempunyai tugas dan fungsi yang sama baik dalam bidang legislasi, anggaran maupun pengawasan, selain itu juga dilengkapi dengan hak veto. Dari sini dapat ditarik benang merah, bahwa sistem bikameral yang dianut oleh Indonesia merupakan soft bikameral, karena kedua kamar tidak mempunyai kewenangan yang sama.

Kajian Maslahah kekuasaan legislatif dalam membuat dan menetapkan hukum. Dalam sejarahnya kekuasaan tersebut dilaksanakan oleh lembaga Ahlu ahalli wal Aqdi, kemudian dalam masa modern sekarang lembaga ini biasanya mengambil bentuk sebagai majelis syura (parlemen). Terkait fungsi legislasi Dewan Perwakilan Daerah. Penulis menyimpulkan bahwa Dewan Perwakilan Daerah mempunyai kekuasaan legislasi, namun kekuasaanya berbeda denganAhlu al-halli wal Aqdi dalam ketatangeraan Islam. Kalau kita mencermati fungsi legislasi Dewan Perwakilan Daerah hanya sebatas terkait dengan kedaerahan, itu pun fungsi yang dimilikinya tidak secara utuh hanya dapat dan ikut dalam membaham rancangan undang-undang yang berkaitan dengan daerah. Hal ini tentu berbeda dengan kewenanganAhlu al-halli wal Aqdi yang mempunyai kekuasaan yang sangat luas mencakup segala bidang permasalah yang tidak terdapat pengaturanya dalam Al-Qur'an dan Sunnah. Namun, terlepas dari perbedaan tersebut antara Ahlu al-halli wal Aqdi dan Dewan Perwakilan Daerah merupakan lembaga yang mecerminkan representasi dari daerah yang salah satu tugasnya ialah membentuk undang-undang yang akan diberlakukan di dalam masyarakat demi kemaslahatan rakyat dan negara. 


\section{DAFTAR PUSTAKA}

A. Djazuli. (2003). Fiqih Siyasah Implementasi Kemaslahatan Umat dalam Rambu-Rambu Syariah. Jakarta : Kencana Prenada Media Group.

Al Din Umar ,Muhammad Al RaziFakh al Din Bin Dhiya. (1997). Tafsir Fakhr Razi, Lahore: Islamic Publication.

Al Mawardi. (t.t.) Al-Ahkam Al-Shulhaniyyah, Beirut: Dar al-Fikr.

Al-Thabari, Tarikhal_umamwa al-Muluk, Jilid IV.

Abu Ishak al-syatibi. (1975). Al-Itishan. Beirut: Dar al-Ma'rifah.

Asshiddiqie, Jimly. (2012).Perkembangan dan Konsilidasi Lembaga Negara Pasca Reformasi. Jakarta: Sinar Grafika.

Cahyadi, Rahmat Imam. (2016). 'Fungsi Legislasi Dewan Perwakilan Daerah Republik Indonesia dalam Pembentukan Undang-undang Pasca Putusan Mahkamah Konstitusi Nomor 92/PUU-X/2012", Jurnal Visip, Vol.3, No.2.

Harun, Refly. "Membangkitkan (lagi) Energi Perubahan Konstitusi", Makalah disampaikan dalam Pekan Konstitusi UUD 1945, Amandemen, dan Masa Depan Bangsa” yang diselenggarakan DPD bekerjasama dengan ICIS, Kamis, 2 Februari 2012 di Jakarta.

Iqbal, Muhammad. (2014). Fiqih siyasah Kontektualisasi Doktrin Politik Islam. Jakarta: Pramedia Group.

Haq, Hamka, al-syathibi (2007). Aspek teologis konsep maslahah dalam kitab almuwafaqat. Jakarta: Erlangga.

MD, Mahfud. (2011). Perdebatan Hukum Tata Negara Pasca amandemen Konstitusi. Jakarta: Raja Grafindo.

(2010). Perdebatan Hukum Tata Negara Pascaamandemen Konstitusi. Jakarta: Rajawali Press.

Marzuki, Peter Mahmud. (2010). Penelitian Hukum. Jakarta: Kencana Prenada.

M. Yusuf, (2013). Dewan Perwakilan Daerah Republik Indonesia Arsitektur histori, Perandan Fungsi DPD RI Terhadap Daerah di Era Otonomi Daerah. Yogyakarta: Grahallmu.

Nurdiani, Ipana. "KewenanganDewanPerwakilan Daerah dalamPembentukanUndang-UndangMenurutUndang-UndangDasar 1945”, Citizenship, Vol.1, No.1,Juli 2011. 
Pirmansyah, M. (2014). Eksistensi Dewan Perwakilan Daerah Dalam Sistem Bikameral di Indonesia. Jurnal Cita Hukum, 2(1). doi:https://doi.org/10.15408/jch.v1i1.1461

Romli, (1999). Muqaramah Mazahib Fil Ushul, Jakarta: Gaya Media Permata.

Sjadzali, Munawir. (2012). Islam dan Tata Negara Ajaran, Sejarah dan Pemikiran. Jakarta: Universitas Indonesia Pers.

Nirahua, S. E. (2011). Kedudukan dan Kewenangan Dewan Perwakilan Daerah dalam Sistem Ketatanegaraan Indonesia. Jurnal Hukum Ius Quia Iustum, 18(4), 585-603.

Tutik, Titik Triwulan. (2017). Restorasi Hukum Tata Negara Indonesia Berdasarkan Undang-Undang Dasar Negara Republik Indonesia Tahun 1945, Depok : Prenadamedia Group.

Undang-undang Republik Indonesia Nomor 17 Tahun 2014 Tentang Majelis Permusyawaratan Rakyat, Dewan Perwakilan Daerah dan Dewan Perwakilan Rakyat Daerah.

Zahroh, Muhammad Abu. (t.t.). Tarik Al Madzahib Al Islamiyat fi al Siyasahwa al Aqidah. Beirut: Dar al Fikr Al Arab. 